\title{
Evaluation of HBV and HCV Seroprevalence in Serum Samples of Individuals Diagnosed with Hepatocellular Carcinoma
}

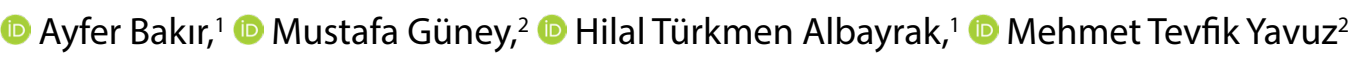 \\ 'Department of Medical Microbiology, University of Health Sciences, Gulhane Training and Research Hospital, \\ Ankara, Turkey \\ ${ }^{2}$ Department of Medical Microbiology, University of Health Sciences, Gulhane Faculty of Medicine, Ankara, Turkey
}

Please cite this article as: Bakır A, Güney M, Türkmen Albayrak $\mathrm{H}$, Yavuz MT. Evaluation of HBV and HCV Seroprevalence in Serum Samples of Individuals Diagnosed with Hepatocellular Carcinoma. Anatol J Family Med 2020;3(2):116-120.

Address for correspondence: Dr. Ayfer Bakır. Department of Medical Microbiology, University of Health Sciences, Gulhane Training and Research Hospital, Ankara, Turkey

Phone: +90 5466272018

E-mail: dr.ayfer.bakir@gmail.com

Received Date: 31.07.2019

Accepted Date: 31.03 .2020

Published online: 21.08 .2020

(C) Copyright 2020 by Anatolian Journal of Family Medicine -

Available online at

www.anatoljfm.org

OPEN ACCESS

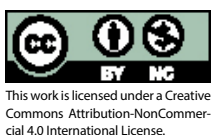

\section{ABSTRACT}

Objectives: According to the data of the World Health Organization, hepatocellular carcinoma (HCC) is the fifth most common cancer and the second leading cause of cancer-related deaths. This study aimed to investigate the importance of hepatitis B virus (HBV) and hepatitis C virus (HCV) in the viral etiology of HCC. In this study, we evaluated HBsAg and anti-HCV test results in serum samples sent with the diagnosis of HCC to Virology Laboratory.

Methods: This study was planned as a record-based cross-sectional study. The patients with HCC who were analyzed HBsAg and anti-HCV antibody in serum specimens in Virology Laboratory between October 2016 and December 2018. HBsAg and anti-HCV were tested in serum samples with test parameters chemiluminescent micro-particular enzyme immunoassay method by Architect system.

Results: This study included 44 patients with HCC. The median age of the patients diagnosed with HCC was 64.0 (33.0-88.0) years. Thirty-six (81.8\%) of the patients were male, and 8 (18.2\%) were female. HBsAg seropositivity was found in $13(29.5 \%)$ patients and anti-HCV seropositivity was found in 2 (4.6\%). HBsAg seropositivity was found in $2(25.0 \%)$ of female patients and $11(30.6 \%)$ of male patients $(p=0.755)$. Anti-HCV seropositivity was found in $2(5.6 \%$ ) male patients ( $p=0.666$ ). The highest HBsAg rate was $35.3 \%$ in the age group of $50-69$ years, and the highest anti-HCV rate was $14.3 \%$ in the age group of $70-88$ years ( $p=0.415, p=0.407$, respectively).

Conclusion: As a result, HBsAg seropositivity was found in $29.5 \%$, and anti-HCV seropositivity was found in $4.6 \%$ of the patients diagnosed with HCC. HBV still keeps its importance in the etiology of HCC.

Keywords: Hepatitis B virus; hepatitis C; enzyme immunoassay; hepatocellular carcinoma.

\section{INTRODUCTION}

Hepatocellular carcinoma (HCC) is the most common primary liver malignity and one of the leading causes of cancer-related deaths around the world. ${ }^{[1]} \mathrm{HCC}$ is the fifth most common cancer in men and seventh in women around the world and the second most common cause of cancer-related deaths. ${ }^{[2,3]}$ Chronic viral hepatitis, cirrhosis, alcoholism and hepatosteatosis are among the risk factors of HCC. ${ }^{[4]}$ Worldwide incidence of HCC varies according to the risk factors. Etiology of approximately $90 \%$ of HCC is known, and it is most commonly associated with chronic viral hepatitis $B$ and $C$, alcohol consumption and aflatoxin exposure..$^{[5]}$ Eighty percent of HCC cases are seen in developing countries, such as SubSaharan Africa and Asia-Pacific regions, and the leading risk factor is the hepatitis $B$ virus (HBV) infection. The leading risk factor in developed countries, such as the USA, Europe and Japan, is the hepatitis $C$ virus (HCV) infection. ${ }^{[6]}$ As it can be understood here, it was found 
that HBV infections that were the main causes of HCC had been replaced by HCV infections in countries where neonatal HBV vaccination program was implemented, such as developed countries.

Approximately $54 \%$ of the cases worldwide are attributed to $\mathrm{HBV}$ infection and $31 \%$ to $\mathrm{HCV}$ infection. ${ }^{[5]} \mathrm{HCC}$ rates vary according to age, gender and race in different geographical regions. Moreover, it is also related to the differences in the prevalence of hepatitis virus and the age when the infection occurs. ${ }^{[3]}$ Tumorigenesis may be seen in all the cirrhosis cases that arise from different etiological factors; however, the risk of tumorigenesis is higher in patients with chronic viral hepatitis. Generally, HCC occurs in onethird of the patients with cirrhosis throughout their life. ${ }^{[7]}$ According to the long-term cohort studies, HCC occurs in patients with cirrhosis at a rate of $1-8 \%$ annually. This rate is $2 \%$ in patients with cirrhosis infected with $\mathrm{HBV}$ and $3-8 \%$ in patients with cirrhosis infected with $\mathrm{HCV}^{\left[{ }^{[8,9]}\right.}$

$\mathrm{HBV}$ is a DNA virus belonging to the family Hepadnaviridae. HBV is transmitted by perinatal, parenteral and sexual routes. Perinatal exposure causes chronic infection in 90$95 \%$ of the cases and exposure in childhood causes chronic hepatitis $B$ at a rate of $50 \% .{ }^{[10]}$ The mechanism responsible for carcinogenesis in HBV infection is chronic necroinflammation, followed by fibrous and hepatocyte proliferation. ${ }^{[11]}$ HBV DNA is integrated with the host genome and causes changes in cellular signal transduction and hepatocyte proliferation. ${ }^{[12]} \mathrm{HBV}$ can also encode the oncogenic viral proteins. In addition to viral proteins, HBV genotype and viral load are associated with hepatocarcinogenesis. ${ }^{[10]} \mathrm{HDV}$ superinfection in $\mathrm{HBsAg}$ positive patients is responsible for cirrhosis and HCC occurrence at an earlier age..$^{[13]}$

$\mathrm{HCV}$ belonging to the family Flaviviridae is a positive-sense single-stranded RNA virus. HCV is often transmitted parenterally. Approximately $80 \%$ of the patients infected with HCV progress to chronic hepatitis C. ${ }^{[14]} \mathrm{HCV}$ causes HCC by leading to an inflammatory, fibrogenic and carcinogenic tissue microenvironment in the liver. ${ }^{[15]}$ Meta-analysis studies revealed that the occurrence risk of HCC increased in patients with HCV genotype $1 \mathrm{~b}$ and genotype $3 .{ }^{[16,17]}$ Occurrence rate of $\mathrm{HCC}$ is between $0.5 \%$ and $0.8 \%$ annually in patients with chronic HCV and between $1.4 \%$ and $2.5 \%$ in patients with cirrhosis. ${ }^{[18]} \mathrm{HCC}$ occurrence risk is higher in patients with coinfection than in patients with chronic HBV and HCV infections alone. ${ }^{[19]}$

In this study, we evaluated the results of HBsAg and anti$\mathrm{HCV}$ tests in serum samples sent with the diagnosis of HCC to the Virology Laboratory and aimed to investigate the importance of HBV and HCV in the viral etiology of HCC.

\section{METHOD}

This study was planned as a record-based cross-sectional study. The patients with HCC who were analyzed HBsAg and anti-HCV antibody in serum specimens in Virology Laboratory between October 2016 and December 2018. HBsAg (Architect HBsAg Qualitative II Reagent Kit, Abbott, Germany) and anti-HCV (Architect Anti-HCV Reagent Kit, Abbott, Germany) test parameters in serum samples sent with the diagnosis of HCC to the Virology Laboratory between October 2016 and December 2018 were tested with Architect system (Architect i2000SR, Abbott, USA) and chemiluminescent microparticle enzyme immunoassay method.

The architect system calculates the test results using the Sample RLU/Cut-off RLU (S/Co) ratio for HBsAg and anti-HCV tests. $S / C o$ value is accepted as reactive if the value is $\geq 1$.

Based on the data collected in this study, SPSS 25 software (SPSS Inc, Chicago, IL, USA) was used for statistical evaluation. Continuous data were given as median and minimum-maximum value, while categorical data were given as freqeuncy and percentages. Compliance of the variables with the normal distribution was assessed by visual methods (histogram and probability graphs) and KolmogorovSmirnov test. Nonparametric results were compared using the Mann-Whitney $U$ test. Pearson Chi-Square or Fisher exact tests were used in the comparison of the qualitative variables. The results with a $p$-value under 0.05 were accepted statistically significant.

\section{RESULTS}

This study included 44 patients with HCC. The median age of the patients diagnosed with HCC was 64.0 (33.0-88.0) years. Male/Female rate was $4.5 / 1$. Median age of male patients was $63.5(45.0-85.0)$ years and that of female patients was $65.5(33.0-88.0)$ years $(p=0.831)$. HBsAg seropositivity was found in 13 (29.5\%) of the patients and anti-HCV was found in 2 (4.6\%) of the patients. Median ages of HBsAg and anti-HCV positive patients were 63.0 (53.0-71.0) years and 63.5 (54.0-73.0) years, respectively. HBsAg seropositivity was found in 2 (25.0\%) of female patients and 11 (30.6\%) of male patients $(\mathrm{p}=0.755)$. Anti-HCV seropositivity was found in $2(5.6 \%)$ males $(p=0.666)$ (Table 1). The highest rate of HBsAg was 12 (35.3\%) between the ages of 50 and 69 and the highest rate of anti-HCV was 1 (14.3\%) between the ages of 70 and 88 ( $p=0.415, p=0.407$, respectively) (Table 2 ).

\section{DISCUSSION}

The global distribution of HCC is associated with the prevalence of dominant risk factors. HBsAg prevalence around 
Table 1. Demographic data of the patients diagnosed with hepatocellular carcinoma

\begin{tabular}{|c|c|c|c|}
\hline Variable & & Age (years) & $\mathbf{p}$ \\
\hline Gender & n (\%) & Median (min-max) & \\
\hline Male & $36(81.8)$ & $63.5(45.0-85.0)$ & $0.831^{*}$ \\
\hline Female & $8(18.2)$ & $65.5(33.0-88.0)$ & \\
\hline Total & $44(100.0)$ & $64.0(33.0-88.0)$ & \\
\hline Etiology & Male $(n=36)$ & Female $(n=8)$ & \\
\hline HBsAg & n (\%) & n (\%) & \\
\hline Positive & $11(30.6)$ & $2(25.0)$ & $0.755^{* *}$ \\
\hline Negative & $25(69.4)$ & $6(75.0)$ & \\
\hline Anti-HCV & n (\%) & n (\%) & \\
\hline Positive & $2(5.6)$ & $0(0.0)$ & $0.666^{* *}$ \\
\hline Negative & $34(94.4)$ & $8(100.0)$ & \\
\hline
\end{tabular}

Table 2. HBsAg and anti-HCV seropositivity rates according to the age groups

\begin{tabular}{lccccc}
\multicolumn{5}{c}{ Age group (years) } \\
$\mathbf{n ~ ( \% )}$ \\
\cline { 2 - 6 } & $\mathbf{3 3 - 4 9}$ & $\mathbf{5 0 - 6 9}$ & $\mathbf{7 0 - 8 8}$ & All ages & $\mathbf{p}$ \\
\hline HBsAg & $0(0.0)$ & $12(35.3)$ & $1(14.3)$ & $13(29.5)$ & 0.415 \\
Anti-HCV & $0(0.0)$ & $1(2.9)$ & $1(14.3)$ & $2(4.5)$ & 0.407 \\
\hline Pearson Chi-Square test. & & & & \\
\hline
\end{tabular}

the world varies geographically. While the low prevalence of HBV infection is in North America, Australia, West and North Europe as $<2 \%$, it is $2-7 \%$ in middle endemic regions, such as East and South Europe and the Middle East. The highest prevalence of HBV infection is in China, Southeast Asia and Sub-Saharan Africa as $>8 \% .^{[20,21]} \mathrm{HBsAg}$ seroprevalence in our country is reported as between $2 \%$ and $7 \% .{ }^{[22]}$

HBsAg seroprevalence is quite variable among patients with HCC. HBV rates in HCC cases are reported as $13-15 \%$ in Europe, $9-45 \%$ in America, $22-41 \%$ in Asia and $27-45 \%$ in Africa. ${ }^{[5]}$ In studies on patients diagnosed with $\mathrm{HCC}, \mathrm{HBsAg}$ positivity rates were found between $22.5 \%$ and $68.0 \%$ in our country. ${ }^{[23-30]}$ Additionally, when compared with positive results stated in different geographic regions around the world, this rate was found higher than the rates of European and Asian countries and similar to the rates of America and Africa. In our study, the HBsAg positivity rate was $29.5 \%$. This rate found in patients diagnosed with HCC is one of the lowest HBsAg positivity rates compared to the other studies conducted in our country.

Implementations of vaccination against HBV have led to decrease in the prevalence of HBV carriers and contributed to the prevention of HCC. ${ }^{[31]}$

It is estimated that global HCV prevalence is $2.5 \%$ and this rate considerably varies among different regions. The rates are reported to be 1.8\% in Europe, 1.3\% in America, 2.8\% in Asia, $2.7 \%$ in the Middle East and Africa and $1.8 \%$ in Australia. ${ }^{[32]}$ Anti-HCV seroprevalence rates among the patients with HCC were found as $24-44 \%$ in Europe, $12-31 \%$ in America, $9-55 \%$ in Asia and $11-44 \%$ in Africa. ${ }^{[5]}$ In studies on patients diagnosed with HCC, anti-HCV positivity rates were found between $5.1 \%$ and $28.6 \%$ in our country. ${ }^{[23-30]}$ In our study, anti-HCV positivity rate was $4.6 \%$. This rate found in patients diagnosed with $\mathrm{HCC}$ is the lowest anti-HCV positivity rate compared to the other studies conducted in our country. Although HCC risk is 4-8 times more in men than in women throughout the world, there was no significant difference in age distribution. ${ }^{[33,34]}$ The prevalence of HCC is more in men has become a research subject for laboratory studies. It was found that chronic inflammation was a predisposing factor for liver malignities and IL-1, and IL-6 from inflammatory cytokines had an inducing role in HBV-related HCC occurrence. ${ }^{[32,34]}$ It was revealed that $17 ß$ estradiol in women suppressed IL-mediated inflammatory process in Kupffer cells and decreased hepatocyte proliferation. [35,36] Moreover, although IL-1 was ten times higher in neighbouring tissues of HCC than in normal tissues, this was not observed in women. ${ }^{[37]}$ Sex hormones, such as androgens and oestrogens, show their biological functions by binding to the specific androgen and oestrogen receptors. It was revealed that androgen signalling pathways increased HBV replication. In addition, androgen signalling pathways induce $\mathrm{HCC}$ progression by suppressing $\mathrm{p} 53$ activity and DNA repair. ${ }^{[38]}$ In this study, the highest HBsAg positivity and anti-HCV seropositivity in patients with HCC was found in male patients. Male/Female ratio was found as $4.5 / 1$ in all patients. The predomination of the male gender was similarly reported in the studies conducted in our country. ${ }^{[23-30]}$

Advanced age is also a significant risk factor in HCC occurrence, as well as the presence of cirrhosis and gender. HCC incidence increases by age in all populations and reaches a peak at the age of 70 years. HCC is rarely seen in the first four decades of life except for populations in which HBV is hyperendemic. In Chinese and black African populations, the mean age of the patients with HCC is significantly younger. ${ }^{[3,39]}$ Apart from these populations, while the occurrence risk of cirrhosis and HCC for chronic HCV infections is more significant worldwide in the ages above 60 , this is not valid for chronic HBV infection. HCC risk is inversely correlated with the age when HBV infection occurs. ${ }^{[39,40]}$ In epidemiologicalstudies carried out in patients with $\mathrm{HCC}$ in 
Turkey between 2001 and 2014, it was observed that HCC progression occurred after the fourth decade. ${ }^{[23-30]}$ In this study, which is consistent with other studies and literature in our country, the median age of HBsAg and anti-HCV positive patients with HCC was 63.5 years and 63 years, respectively.

The most important limitations of this study are the small size of the sample and difficulties in establishing a cause and effect relationship with cross-sectional studies. It is believed that the researchers should conduct at least a cohort or case-control studies with more samples in future studies on this subject. Because this study was conducted on the basis of hospital records, all clinical information about the patients could not be reached. Other risk factors (for example, chronic liver disease and cirrhosis) and exposure time that may cause HCC are unknown.

\section{CONCLUSION}

As a result, in this retrospective study, HBsAg seropositivity was found in $29.5 \%$ and anti-HCV seropositivity was found in $4.6 \%$ in the serum samples of the patients diagnosed with HCC. HBV still keeps its importance in the etiology of HCC. It is crucial to develop vaccine programs aimed for the protection of especially new generations against HBV infection and carryout awareness studies in order to inform the populations.

\section{Disclosures}

Peer-review: Externally peer-reviewed.

Conflict of Interest: None declared.

Ethics Committee Approval: This study was performed with the approval of the Non-Interventional Clinical Research Ethical Committee of the University of Health Sciences Gulhane Training and Research Hospital (reference number: 26.02.2019/19/40).

Authorship Contributions: Concept - A.B., Design- A.B., Supervision - M.G., M.T.Y.; Materials - A.B.,H.T.A.; Data collection \&/ or processing - A.B.; Analysis and/or interpretation - A.B., H.T.A.; Literature search - A.B, M.G.; Writing - A.B., M.G.; Critical review M.G., M.T.Y.

\section{REFERENCES}

1. Balogh J, Victor D 3rd, Asham EH, Burroughs SG, Boktour M, Saharia A, et al. Hepatocellular carcinoma: a review. J Hepatocell Carcinoma 2016;3:41-53.

2. Chang IC, Huang SF, Chen PJ, Chen CL, Chen CL, Wu CC, et al. The Hepatitis Viral Status in Patients With Hepatocellular Carcinoma: a Study of 3843 Patients From Taiwan Liver Cancer Network. Medicine (Baltimore) 2016;95:e3284.

3. El-Serag HB. Epidemiology of viral hepatitis and hepatocellu- lar carcinoma. Gastroenterology 2012;142:1264-73.e1.

4. Chen CJ, Yu MW, Liaw YF. Epidemiological characteristics and risk factors of hepatocellular carcinoma. J Gastroenterol Hepatol 1997;12:S294-S308.

5. Global Burden of Disease Liver Cancer Collaboration, Akinyemiju T, Abera S, Ahmed M, Alam N, Alemayohu MA, et al. The Burden of Primary Liver Cancer and Underlying Etiologies From 1990 to 2015 at the Global, Regional, and National Level: Results From the Global Burden of Disease Study 2015. JAMA Oncol 2017;3:1683-91.

6. Rawla P, Sunkara T, Muralidharan P, Raj JP. Update in global trends and aetiology of hepatocellular carcinoma. Contemp Oncol (Pozn) 2018;22:141-50.

7. Sangiovanni A, Prati GM, Fasani P, Ronchi G, Romeo R, Manini $M$, et al. The natural history of compensated cirrhosis due to hepatitis C virus: A 17-year cohort study of 214 patients. Hepatology 2006;43:1303-10.

8. Ioannou GN, Splan MF, Weiss NS, McDonald GB, Beretta L, Lee SP. Incidence and predictors of hepatocellular carcinoma in patients with cirrhosis. Clin Gastroenterol Hepatol 2007;5:938-45.e9454.

9. Lok AS, Seeff LB, Morgan TR, di Bisceglie AM, Sterling RK, Curto $\mathrm{TM}$, et al. Incidence of hepatocellular carcinoma and associated risk factors in hepatitis C-related advanced liver disease. Gastroenterology 2009;136:138-48.

10. Chitapanarux T, Phornphutkul K. Risk Factors for the Development of Hepatocellular Carcinoma in Thailand. J Clin Transl Hepatol 2015;3:182-8.

11. Murakami T, Baron RL, Peterson MS, Oliver JH 3rd, Davis PL, Confer SR, et al. Hepatocellular carcinoma: MR imaging with mangafodipir trisodium (Mn-DPDP). Radiology 1996;200:6977.

12. Liu CJ, Kao JH. Hepatitis B virus-related hepatocellular carcinoma: epidemiology and pathogenic role of viral factors. J Chin Med Assoc 2007;70:141-5.

13. Verme G, Brunetto MR, Oliveri F, Baldi M, Forzani B, Piantino P, et al. Role of hepatitis delta virus infection in hepatocellular carcinoma. Dig Dis Sci 1991;36:1134-6.

14. Suruki RY, Mueller N, Hayashi K, Harn D, DeGruttola V, Raker $C A$, et al. Host immune status and incidence of hepatocellular carcinoma among subjects infected with hepatitis $C$ virus: a nested case-control study in Japan. Cancer Epidemiol Biomarkers Prev 2006;15:2521-5.

15. Hoshida Y, Fuchs BC, Bardeesy N, Baumert TF, Chung RT. Pathogenesis and prevention of hepatitis $C$ virus-induced hepatocellular carcinoma. J Hepatol 2014;61:S79-S90.

16. Raimondi S, Bruno S, Mondelli MU, Maisonneuve P. Hepatitis C virus genotype $1 \mathrm{~b}$ as a risk factor for hepatocellular carcinoma development: a meta-analysis. J Hepatol 2009;50:1142-54.

17. Kanwal F, Kramer JR, Ilyas J, Duan Z, El-Serag HB. HCV genotype 3 is associated with an increased risk of cirrhosis and he- 
patocellular cancer in a national sample of U.S. Veterans with HCV. Hepatology 2014;60:98-105.

18. Bruno S, Silini E, Crosignani A, Borzio F, Leandro G, Bono F, et al. Hepatitis $C$ virus genotypes and risk of hepatocellular carcinoma in cirrhosis: a prospective study. Hepatology. 1997;25:754-8.

19. Chiaramonte M, Stroffolini T, Vian A, Stazi MA, Floreani A, Lorenzoni $U$, et al. Rate of incidence of hepatocellular carcinoma in patients with compensated viral cirrhosis. Cancer. 1999;85:2132-7.

20. Franceschi S, Raza SA. Epidemiology and prevention of hepatocellular carcinoma. Cancer Lett. 2009;286:5-8.

21. Lyon F. IARC monographs on the evaluation of carcinogenic risks to humans. Some industrial chemicals WHO. 1994;60:389433.

22. Tozun N, Ozdogan O, Cakaloglu Y, Idilman R, Karasu Z, Akarca US, et al. A nationwide prevalence study and risk factors for hepatitis A, B, C and D infections in Turkey. Hepatology. 2010;52: 697.

23. Arhan M, Akdoğan M, Mehmet İ, Kiliç ZMY, Kaçar S, Bilge T, et al. Tek merkeze ait hepatosellüler karsinom verileri; retrospektif çalışma. Akademik Gastroenteroloji Dergisi,2009;8:18-23.

24. Uzunalimoğlu O, Yurdaydin C, Cetinkaya H, Bozkaya H, Sahin T, Colakoğlu S, et al. Risk factors for hepatocellular carcinoma in Turkey. Dig Dis Sci. 2001;46:1022-8.

25. Ozer B, Serin E, Yilmaz U, Gümürdülü Y, Saygili OB, Kayaselçuk $\mathrm{F}$, et al. Clinicopathologic features and risk factors for hepatocellular carcinoma: results from a single center in southern Turkey. Turk J Gastroenterol. 2003;14:85-90.

26. Sakar B, Ustuner Z, Karagol H, Aksu G, Camlica H, Aykan NF. Prognostic features and survival of inoperable hepatocellular carcinoma in Turkish patients with cirrhosis. Am J Clin Oncol. 2004;27:489-93.

27. Alacacioglu A, Somali I, Simsek I, Astarcioglu I, Ozkan M, Camci $C$, et al. Epidemiology and survival of hepatocellular carcinoma in Turkey: outcome of multicenter study. Jpn J Clin Oncol. 2008;38:683-8.

28. Akkiz H, Bayram S, Bekar A, Akgöllü E, Üsküdar O. Genetic variation in the microRNA-499 gene and hepatocellular carci- noma risk in a Turkish population: lack of any association in a case-control study. Asian Pac J Cancer Prev. 2011;12:3107-12.

29. Dogan E, Yalcin S, Koca D, Olmez A. Clinicopathological characteristics of hepatocellular carcinoma in Turkey. Asian Pac J Cancer Prev. 2012;13:2985-90.

30. Can A, Dogan E, Bayoglu IV, Tatli AM, Besiroglu M, Kocer M, et al. Multicenter epidemiologic study on hepatocellular carcinoma in Turkey. Asian Pac J Cancer Prev. 2014;15:2923-7.

31. Bosetti C, Turati F, La Vecchia C. Hepatocellular carcinoma epidemiology. Best Pract Res Clin Gastroenterol. 2014;28:753-70.

32. Petruzziello A, Marigliano S, Loquercio G, Cozzolino A, Cacciapuoti $C$. Global epidemiology of hepatitis $C$ virus infection: An up-date of the distribution and circulation of hepatitis $C$ virus genotypes. World J Gastroenterol. 2016;22:7824-40.

33. Montalto G, Cervello M, Giannitrapani L, Dantona F, Terranova $A$, Castagnetta LA. Epidemiology, risk factors, and natural history of hepatocellular carcinoma. Ann N Y Acad Sci. 2002;963:13-20.

34. Ruggieri A, Barbati C, Malorni W. Cellular and molecular mechanisms involved in hepatocellular carcinoma gender disparity. Int J Cancer. 2010;127:499-504.

35. Baldissera VD, Alves AF, Almeida S, Porawski M, Giovenardi M. Hepatocellular carcinoma and estrogen receptors: Polymorphisms and isoforms relations and implications. Med Hypotheses. 2016;86:67-70.

36. Naugler WE, Sakurai T, Kim S, Maeda S, Kim K, Elsharkawy AM, et al. Gender disparity in liver cancer due to sex differences in MyD88-dependent IL-6 production. Science. 2007 ;317:121-4.

37. Levrero M, Zucman-Rossi J. Mechanisms of HBV-induced hepatocellular carcinoma. J Hepatol. 2016;64:84-101.

38. Ma WL, Lai HC, Yeh S, Cai X, Chang C. Androgen receptor roles in hepatocellular carcinoma, fatty liver, cirrhosis and hepatitis. Endocr Relat Cancer. 2014;21:165-82.

39. White DL, Thrift AP, Kanwal F, Davila J, El-Serag HB. Incidence of Hepatocellular Carcinoma in All 50 United States, From 2000 Through 2012. Gastroenterology. 2017 ;152:812-20.

40. Kuper H, Hsieh C, Stuver SO, Mucci LA, Tzonou A, Zavitsanos X, et al. Birth order, as a proxy for age at infection, in the etiology of hepatocellular carcinoma. Epidemiology. $2000 ; 11: 680-3$. 